REVISTA DE LITERATURA E CULTURA RUSSA

\title{
Ser (e deixar de ser) o homem doente, o homem mau e o homem desagradável: notas sobre Memórias do subsolo
}

\author{
To be (and not to be) the sick man, \\ the bad man and the unpleasant \\ man: notes on Notes from the \\ underground
}

Autor: Diego Lock Farina Universidade Federal do Rio Grande do Sul, Porto Alegre, Rio Grande do Sul, Brasil Edição: RUS Vol. 12. N 20 Publicação: Dezembro de 2021 DOI: https://doi.org/10.11606/issn.2317-4765.rus.2021.191500 


\section{Ser (e deixar de ser) o homem doente, o homem mau e o homem desagradável: notas sobre Memórias do subsolo}

\section{Diego Lock Farina*}

Resumo: 0 presente artigo comenta e analisa as estratégias e o percurso narrativo do protagonista anônimo das Memórias do subsolo (1864), de Fiódor Dostoiévski, com o intuito de destacar a pertinência de uma leitura critico-clínica acerca da novela, tendo em vista o estudo das sintomatologias e o diálogo com o pensamento de Gilles Deleuze que diz respeito à literatura como devir, à função do escritor como médico da civilização e ao sujeito larvar das micropolíticas que atua nos efeitos do real e na potência do impossível. 0 texto tem também como objetivo levantar a hipótese ensaística de que o homem do subsolo experencia transcendentalmente um efetivo movimento entre a enfermidade e a saúde do mundo, entre o bem e o mal e, por fim, entre a crítica negativa e a afırmação do desejo na vida, sempre sob vias de transbordar esses limites todos. Para tal aproveitamento, discutese igualmente algumas observações centrais a propósito da obra e/ou da filosofia do tempo de Dostoiévski realizadas por René Girard, Bakhtin, Nietzsche, Sergio Givone, dentre outros. De uma leitura diferencial da novela à leitura da teoria literária contemporânea, o artigo se utiliza das Memórias como um local intensivo de disputas pelo sentido da escrita, da mimese como técnica poética primordial e do gênero textual das confissões, ou melhor, dos castigos correcionais que conjuram por aporias.

\begin{abstract}
This article comments and analyzes the strategies and narrative path of the anonymous protagonist of Notes from the underground (1864), by Fyodor Dostoievski, in order to highlight the relevance of a criticalclinical reading about the novel, with a view to the study of symptomatologies and the dialogue with Gilles Deleuze's thought that concerns literature as becoming, the writer's role as a physician of civilization and the larval subject of micropolitics that acts on the effects of the real and on the potency of the impossible. The text also aims to raise the essay hypothesis that the underground man experiences transcendentally an effective movement between illness and health in the world, between good and evil and, finally, between negative criticism and the affirmation of desire in life, always on the way to overflowing all these limits. For this purpose, some central observations concerning the work and/or philosophy of Dostoievski's time, carried out by René Girard, Bakhtin, Nietzsche, Sergio Givone, among others, are also discussed. From a differential reading of the novel to the reading of contemporary literary theory, the article uses the Memoirs as an intensive place for disputes over the meaning of writing, mimesis as a primordial poetic technique and the textual genre of confessions, or rather, correctional punishments that conjure by aporias.
\end{abstract}

Palavras-chave: Memórias do subsolo; Devir literário; Sintomatologia; Deleuze Keywords: Notes from the underground; Literary becoming; Symptomatology; Deleuze 
* Universidade Federal do Rio Grande do Sul (UFRGS). Doutor em Estudos de Literatura - Teoria, Crítica e Comparatismo. Autor do livro Todos os lados da rua - finalista do Prêmio Açorianos de Criação Literária em 2013. Tradutor e membro da equipe editorial da Revista Dystopia, 0 não-lugar da crítica; http://lattes.cnpq. br/6876164288108555; https:// orcid.org/0000-0003-0362-564X; diegolockfarina@hotmail.com

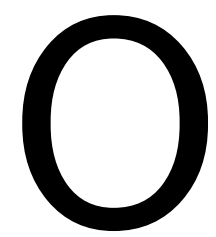

homem do subsolo de Dostoiévski é, sem dúvida, uma figura emblemática para o século XIX - e do século de Darwin e Marx, para fora dele. Uma figura atemporal, melhor dizendo, em determinado nível empírico-transcendental, ${ }^{1}$ que "verifica a irredutível falta de fundamento da experiência";" uma figura sem nome anunciado (resistente ao nomos, à materialização da lei humana) que, entretanto, foge da própria figuração e que acompanha seu contemporâneo Bartleby num sentido talvez obscuro, sintomático e acontecimental. Eis então o paradoxalista exemplar, o anti-herói das memórias escritas aos quarenta anos, o neurótico e o histérico, o duplo que se choca com a multiplicidade do mundo, o homem geral que nunca houve e que, contudo, sempre existiu. O filósofo novelista, do embuste alegórico à meditação formal, o kantiano confessional (que critica a verdade das confissões de Rousseau), amante do furor romântico heterogênico e da cultura bela e sublime, o ressentido que abrirá os olhos de Nietzsche aos males do ressentimento, a voz verborrágica à qual nin-

\footnotetext{
1 A realidade do homem do subsolo é distribuída sob uma vida plenamente imanente; seu plano de imanência é o próprio subsolo. 0 empirismo-transcendental, do qual nos fala Gilles Deleuze (2016, p. 178), parece caber para avaliar o tipo de inscrição na experiência realizada pelo personagem. A definição do conceito auxilia na compreensão desse campo praticamente cosmológico, que escapa e faz escapar da configuração fenomenológica: "0 que é um campo transcendental? Ele se distingue da experiência, enquanto não remete a um objeto nem pertence a um sujeito (representação empírica). No mais, ele se apresenta como pura corrente de consciência assubjetiva, consciência pré-reflexiva impessoal, duração qualitativa da consciência sem eu. Pode parecer curioso que o transcendental se defina por tais dados imediatos: falar-se-á de empirismo transcendental em oposição a tudo aquilo que faz o mundo do sujeito e do objeto. Há qualquer coisa de selvagem e de potente num tal empirismo transcendental. Não é certamente o elemento da sensação (empirismo simples), pois a sensação não é mais que um corte na corrente de consciência absoluta. É sobretudo, por mais próximas que sejam duas sensações, a passagem de uma a outra como devir, como aumento ou diminuição de potência (quantidade virtual). Por conseguinte, deve-se definir o campo transcendental pela pura consciência imediata sem objeto nem eu, enquanto movimento que não começa nem termina? (Mesmo a concepção espinosista da passagem ou da quantidade de potência faz apelo à consciência)".
}

2 GIVONE, 2009, p. 470. 
guém melhor que Beckett ${ }^{3}$ saberá dar prosseguimento, o mote para especular o inconsciente, o suspeito composto sadismo-masoquismo, e o veio para anteceder a tipologia existencialista de um século mais tarde. As entradas serão diversas. E a acumulação crítica, desde então, inevitável.

O monólogo das Memórias do subsolo - escrito para se tornar sério: "o papel tem algo que intimida" culpa como aparentes fios condutores. Raiva, por exemplo, da condição humana e das leis naturais; culpa, dentre outras, por ser "mais inteligente que todos à minha volta" ${ }^{5}$ e por não ter feito nada para mudar materialmente a vida de parasita. A composição das notas mnemônicas, dessa forma, auxilia o personagem narrador em seu processo, difusamente declarado, de tomar consciência de si frente à própria contingência, por sua vez, refletida de um passado distante que o afetou a partir de uma série de traumas bastante pontuais - aventuras humilhantes, eventos supostamente menores, que passariam despercebidos por muita gente. O personagem, portanto, ao narrar-se para leitores espectrais, desloca-se de uma sinistra posição de angústia emudecida para uma nova empreitada, eufórica, diga-se de passagem, em que seu ser ambíguo e irresoluto se concretiza porque torna-se literário. Contemplando-se sob a forma das letras, pode o protagonista enfim iniciar seu tratamento. Um tratamento conturbado, decerto, mas que, à medida que se desenvolve, revela as fraquezas que o constituem e o deixam perplexo ao ganharem a visibilidade que nem ele seria capaz de imaginar. O caráter patológico que engendra o tom das Memórias - que logo assinalaremos como relativo, aporético - advém de uma doença, inclusive, conhecida, denominada como hipertrofia da consciência, que leva à introspeç̧ão do personagem "até o mais cruel desdobramento, que o faz se tornar vítima e carrasco de si mesmo". ${ }^{6} \mathrm{O}$ "tagarelismo

3 Cf. BECKETT, Samuel. Linnommable. Paris: Les Éditions de Minuit, 2000.

4 DOSTOIÉVSKI, 2009, p. 54.

$5 \mathrm{Ibid}, \mathrm{p} .21$.

6 GIVONE, 2009, p. 468. 
inofensivo"7 das memórias, nessa sequência, conecta-se inevitavelmente à virtualidade filosófica de uma maneira muito especial, a ponto de fazer de seu objeto narrado um sujeito de devires, que, por seu turno, projeta ainda o ensaio de uma filosofia do desejo: "que é um homem sem desejos, sem vontades nem caprichos, senão um pedal de órgão? (...) o ato de querer constitui a manifestação de toda a vida". ${ }^{8}$ Afinal, ainda a respeito do devir, "um homem inteligente não pode, a sério, tornar-se algo (...) um homem inteligente do século XIX precisa e está moralmente obrigado a ser uma criatura iminentemente sem caráter". ${ }^{9}$ A moral do sem caráter, espécie de postura anti-maniqueísta, macunaímica por associação livre, desvela nesse caso a inscrição de um sujeito melancólico, recalcado e subtraído que se encontra fadado aos movimentos, às oscilações, aos modos cíclicos de um projeto literário em devir que não chega nunca a tornar-se em definitivo, pois sua intensidade reside propriamente no percurso para ser, no projetismo não-teleológico, e não em quaisquer produtos ou representações que lhe dariam corpo e o jogariam no mundo dos outros, que tanto o aflige e o faz enterrar-se vivo por antecipação: "o homem é uma criatura volúvel e pouco atraente e, talvez, a exemplo do enxadrista, ame apenas o processo de atingir o objetivo, e não o próprio objetivo". ${ }^{10} \mathrm{O}$ conceito de inteligência para o narrador, que acena para uma poética da belle irresponsabilité da qual Nietzsche era entusiasta, ${ }^{11}$ atenta-se, com efeito, a essa nuance: "É possível que me considere um homem inteligente apenas porque, em toda a vida, não pude começar nem acabar coisa alguma". ${ }^{12}$ Contudo, a zombaria nunca foge por completo de seu horizonte: "Mas que fazer, se a destinação única e direta de todo homem inteligente é apenas a tagare-

7 DOSTOIÉVSKI, 2009, p. 30.

$8 \mathrm{lbid}, \mathrm{p.} 41$.

$9 \mathrm{Ibid}, \mathrm{p} .17$.

$10 \mathrm{lbid}, \mathrm{p} .46$.

11 Nietzsche via como uma tarefa dar à irresponsabilidade seu sentido positivo. Cf. DELEUZE, 2018

12 DOSTOIÉVSKI, 2009, p. 30. 
lice, uma intencional transferência do oco para o vazio?". ${ }^{13} \mathrm{O}$ muitas vezes referido niilismo do subsolo deve ser observado com certo distanciamento e suspeita, pois a chave de leitura satírica das entrelinhas das Memórias pode desativá-lo a qualquer instante. Antes de passarmos adiante, vejamos um exemplo fortuito trazido por Deleuze e Guattari que distingue a imitação (leia-se, em conjunto, a mímese) da potência dos devires, levando sempre em consideração que a literatura, ou então mesmo somente "escrever é um caso de devir, sempre inacabado, sempre em via de fazer-se, e que extravasa qualquer matéria vivível ou vivida. É um processo, ou seja, uma passagem de Vida que atravessa o vivível. A escrita é inseparável do devir"; 14

Devir nunca é imitar. Quando Hitchcock faz o pássaro, ele não reproduz nenhum grito de pássaro, ele produz um som eletrônico como um campo de intensidades ou uma onda de vibrações, uma variação contínua, como uma terrível ameaça que sentimos em nós mesmos (...) A tarantela é a estranha dança que conjura ou exorciza as supostas vítimas de uma picada de tarântula: mas, quando a vítima faz sua dança, pode-se dizer que ela está imitando a aranha, que se identifica com ela, mesmo numa identificação de luta 'agonística', arquetípica? Não, pois a vítima, o paciente, o doente, não devém aranha dançante a não ser na medida em que a aranha por sua vez é suposta devir pura silhueta, pura cor e puro som, segundo os quais o outro dança. Não se imita; constitui-se um bloco de devir, a imitação não intervém senão para o ajuste de tal bloco, como uma última preocupação de perfeição, uma piscada de olho, uma assinatura. Mas tudo o que importa passou-se em outro lugar: devir-aranha da dança, à condição de que a aranha devenha ela mesma som e cor, orquestra e pintura. ${ }^{15}$

Se Nietzsche, noutro âmbito, foi um Dostoiévski mais grosseiro, como afirmou certa feita Gorki ${ }_{1}^{16}$ Além do bem e do mal

13 Ibid, p. 31.

14 DELEUZE, 2011, p. 11.

15 DELEUZE; GUATTARI, 2012, p. 113.

16 A referência é na verdade uma anotação, publicada na revista Rúskaia Litieratura, $n^{\circ} 2$, de 1968, citada por Boris Schnaiderman no prefácio da edição das Memórias da editora 34. Dirá Máximo Gorki: "Para mim, todo Nietzsche está em Memórias do subsolo. Neste livro 
pode ser visto, sob a luz dos deslizamentos comparatistas, como as Memórias menos requintadas. Acerca desse encontro, que aqui não exploraremos extensivamente, gostaríamos apenas de citar três passagens da obra que auxiliam na sustentação da nossa hipótese final. A primeira trata da diferença entre o bem-estar, o acomodar-se, a aceitação passiva dos homens do dever e o que Nietzsche define como a disciplina do sofrimento, praticada por Nós, os imoralistas, os filósofos do futuro: "bem-estar (...) isso não é uma meta, isso nos parece um final! Um estado que torna o homem imediatamente ridículo e desprezível (...) A disciplina do sofrimento (...) apenas essa disciplina produziu todas as elevações do homem até agora" ${ }^{17} \mathrm{~A}$ segunda passagem, de caráter mais enigmático, tensiona um dos aspectos mais sensíveis das Memórias, que provoca, por sua vez, a moral do orgulho que barra, coíbe, o fluxo das reminiscências: "Eu fiz isso', diz minha memória. 'Não posso ter feito isso' - diz meu orgulho, e se mantém inexorável. Por fim - a memória cede"18 - o que ocorre nessa cedência? A terceira e última, portanto, aborda a solidão como forma para o encontro daquilo que ultrapassa o sistema binário do bem e do mal, e tem como porvir a saúde da multiplicidade: "O maior será aquele que puder ser o mais solitário, o mais oculto, o mais divergente, o homem além do bem e do mal, o senhor de suas virtudes, o riquíssimo em vontade (...) poder ser tão múltiplo quanto inteiro, tão vasto quanto pleno". ${ }^{19}$

O homem do subsolo, portanto, debate-se em sua toca espacial e ao mesmo tempo pensante, remoendo-se com os remorsos mais alucinatórios, com os índices precários do cotidiano, submerso em seus prazerezinhos secretos, seus segredinhos sujos (devassos) e, assim, cumpre com o que considera o único prazer digno a um homem decente: falar de si mesmo. 0 narcisismo do personagem é, no entanto, enviesado, às vezes

- e até hoje não o sabem ler - se dá para toda Europa a fundamentação do niilismo e do anarquismo. Nietzsche é mais grosseiro que Dostoiévski".

17 NIETZSCHE, 2010, p. 162.

18 Ibid, p. 92.

19 Ibid, p. 151. 
enganoso; é talhado pelo estilo do manipulador que por estratégia mente: como já adiantado acima, no comentário sobre Rousseau, ao avisar indiretamente que toda confissão envolve a mentira, o narrador dá a entender que, ao confessar, está fadado à inverdade, inclusive por adequação a esse gênero textual. De fato, levando isso em consideração, pode-se acreditar na autenticidade do que ocorre na descrição das aventuras? É possível sempre duvidar do que aconteceu em seus relatos, e o próprio narrador abre brecha para que o leitor desconfie dele, porque, afinal, é de seu agrado parecer um crápula ou mesmo parecer repugnante, pois há nele uma "singular forma de perversão que consiste em se deixar seduzir pela própria capacidade de extrair do fundo da alma materiais sórdidos e abjetos (...) mostra como sempre existe uma intenção, um desejo na raiz de toda e qualquer maldade". ${ }^{20}$ Embora arrogante e dono de uma suposta autoestima elevada, o anti-herói das Memórias pode também ser visto enquanto um sujeito larvar, ${ }^{21}$ que sequer consegue se transformar num inseto (deixa que Kafka soube capturar mais tarde), um habitante rastejante dos territórios ulteriores de uma metrópole como São Petersburgo - "a cidade mais abstrata e meditativa de todo o globo terrestre. (Existem cidades meditativas e não meditativas)". ${ }^{22}$ Um narciso tóxico - na superfície do que quer informar - que extrai satisfação da própria degradação, da experiência com a proximidade com os derradeiros limites. E que, de certo modo ainda

\footnotetext{
20 GIVONE, 2009, p. 469.

21 Aqui, dirigimo-nos à noção de sujeito larvar desenvolvida por Gilles Deleuze: "temos observado que o sujeito ao qual se dirige Deleuze é um sujeito mutante, parcial, em pleno devir, fragmentado entre seus modos de individuação sempre incompletos e momentâneos; trata-se, afınal, do sujeito larvar descrito em Diferença e repetição, em que o eu já está dissolvido e aparece então como produto de uma máquina de contrair; o eu é ele-próprio modificação, designando uma diferença transvasada à repetição. 0 sujeito larvar é antes de mais nada o sujeito em devir, indecidível e problemático. Giorgio Agamben falará de um ser semelhante à medida que discorre sobre o conceito de qualunque em A comunidade que vem: 'o ser que vem é o ser qualquer', qualquer um, seja quem for, qual-se-queira (refugiado, migrante, apátrida), o que não significa falar de uma generalidade universal, como tentava a ontologia. Tal sujeito está inevitavelmente em relação com o desejo, com o afecto, que é o interessante por definição, e a maneira pela qual ele passa do comum ao próprio e do próprio ao comum se chama uso - ethos. Esse larvar qualquer é, nesse sentido, o acontecimento de um fora" (FARINA, 2021, p. 102).
}

22 DOSTOIÉVSKI, 2009, p. 18. 
ardiloso, apela sussurradamente para que se sinta pena dele. As contradições serão muitas e a oscilação do humor - o que poderia suscitar o diagnóstico elementar de uma bipolaridade nervosa - é por fim sua característica essencial, e é a partir dela que se deve vislumbrar essa figura que tanto mais se abstraia de si, mais adquire a consciência de que não há como admirá-lo: a não ser, contudo, pelo viés último da sua inteligência literária, a aposta derradeira e desesperada de projetar suas memórias ao mundo, com a esperança de que a partir delas possa haver algum tipo de redenção estética, que cumpra com o ideal do belo e sublime e que, além disso, confirme a afirmação do fim das notas, de que um dia algo ainda nascerá das ideias. Que lastro profético pode haver nisso tudo? O próprio devir-imperceptível desse micróbio larvar talvez seja tão imperceptível que acaba por tornar-se capaz de sustentar a força do homem do subsolo até os dias de hoje.

Devido à condição social empobrecida, à orfandade, à falta de oportunidades e favorecimentos, o protagonista mora no subúrbio, embaixo da terra, como o futuro roedor da Construção de Kafka, e sobrevive precariamente com a renda da aposentadoria do funcionarismo público do Tsar. Sua confiança, sua impressão de status e todo o seu orgulho vêm do capital cultural adquirido através das leituras e do aprimoramento do senso estético; é o modo que encontra, desde a escola, para fazer frente aos companheiros mais abastados. A degradação ilustre que desenvolve - o que René Girard prefere chamar por "inferioridade generalizada"23 -, alia-se à inércia social (os homens de pensamento nada fazem) e é no desespero constante que é manifestado o seu lugar irrealocável para ser, para restar ou devir o resíduo das máquinas imperiais, para elevar-se à qualidade de um autêntico, de um original em meio às massas desumanizadas, à classe média medíocre e mimética, às elites pouco ilustradas e facilmente afetadas pelo fetiche francês, inglês ou alemão. É evidente que na pena afiada de Dostoiévski essa degradação ilustre aparece como uma ironia sofisticada, sobretudo para encaminhar sua crítica ao positivismo

23 GIRARD, 2011, p. 46. 
da época e à irretrucável aritmética da vida empreendida pela voga cientificista, pela dominação racionalista que já tomava conta do continente europeu, ou seja, a tudo que o "impossível quer dizer um muro de pedra". ${ }^{24}$ Sabemos, por fim, que uma das teses mais célebres das Memórias se baseia em $2+2=5$ e que sua metafísica parte, incialmente, dessa confrontação teórica: "na realidade, dois e dois não são mais a vida, meus senhores, mas o começo da morte". ${ }^{25}$ Observemos o sentido crítico e sarcástico que é mobilizado numa passagem como essa:

E eu poderia, neste caso, escolher uma carreira para mim: seria preguiçoso e comilão, não do tipo comum, mas, por exemplo, dos que comungam com tudo o que é belo e sublime (...) E exigiria por isto respeito a mim mesmo, e perseguiria quem não me tributasse esse respeito. Vive-se com tranquilidade, morre-se solenemente... é o encanto, um verdadeiro encanto! $E$ eu criaria um tal barrigão, armaria um tal queixo tríplice, elaboraria um tal nariz de sândalo que todo transeunte diria, olhando para mim: "Este é que é um figurão! Isto que é verdadeiro e positivo!" Seja o que quiserdes, mas é agradabilíssimo ouvir opiniões assim em nosso século de negação, meus senhores. ${ }^{26}$

Há, assim, três episódios narrados pelo autor das Memórias, cuja série que se forma no encadeamento deles denota a progressão de seu estado permanente de angústia. As três aventuras constrangedoras ou andanças-trauma, como referimos há pouco, expressam a problematização decorrente de acontecimentos que ferem seu orgulho. A primeira, patética do início ao fim, lança luz à necessidade psicótica do narrador de buscar quixotescamente potenciais rivais. Após adentrar uma taverna onde ocorria uma briga, com o desejo inusitado de tomar parte do conflito desconhecido e hilariamente ser atirado pela janela, o protagonista inominado é simplesmente retirado pelos ombros do lugar que estava por um militar que queria passagem. Tal sujeito sequer nota o homem do subsolo, segundo a narração, e por isso fere brutalmente seus brios que, aliás, só se sustentam em seus sonhos ou nos delírios solitá-

24 DOSTOIÉVSKI, 2009, p. 24.

$25 \mathrm{Ibid}, \mathrm{p} .47$.

$26 \mathrm{lbid}$, p. 32. 
rios e solipsistas da vida subterrânea. Quando deparado com o mundo concreto, toda a ilusão de superioridade se esfumaça em segundos. O narrador, sendo assim, decide que é preciso se vingar daquele sujeito arrogante. Nota-se desde aqui que a disputa pela hierarquia das arrogâncias é um dilema recorrente que o protagonista cria para si. A vingança se baseia em persegui-lo durante dias até preparar-se ridiculamente para esbarrar com ele, de propósito, na avenida central da cidade (para isso chega a pedir dinheiro emprestado para seu ex-chefe, Antón Antônitch, para vestir-se decentemente, para estar no nível do rival) e, desse modo, interromper seu passeio e ser notado pelo inimigo fictício que sequer sabe da sua existência. O que ocorre, então, é que, ao finalmente se esbarrarem, o oficial militar apenas olha para trás por um instante e logo segue seu rumo, pouco se importando com a situação, enquanto que o protagonista sente-se orgulhoso de seu feito minúsculo. A ilusão da recuperação do que julga como decência é o que move sua persistência na vida e faz com que resista a si mesmo.

O segundo episódio, tal qual deplorável, envolve um jantar com ex-colegas, para o qual teve que convidar-se para ir, e para o qual não era, obviamente, bem-vindo. Novamente precisa pedir dinheiro emprestado, mais de uma vez, aliás, por fim pedindo para um dos rapazes (Símonov) para ir ao bordel. A janta simbolizava a despedida de um deles, Monsieur Zvierkóv, jovem gabola e nobre, admirado exageradamente pelos companheiros um tanto submissos, que ostentava uma posição honrada na sociedade e fazia inveja ao narrador. É o ódio do protagonista que o arrasta à imprudência de comparecer ao evento. Como comenta Girard, ${ }^{27}$ aqui destaca-se o feitio prometeico de seu orgulho. Junto a isso, o direito ao capricho, que o narrador parece a todo tempo reivindicar, alastra-se à enésima potência. Durante o jantar, ele é desprezado e humilhado de todas as formas; embebeda-se, discute, ofende Zvierkóv ao homenageá-lo separadamente e de maneira insólita, desapropriada, e, dessa maneira, acaba sendo hostilizado e evitado por

27 GIRARD, 2011. 
seus novos adversários. A rivalidade do homem do subsolo é sempre unilateral, paranoica e lamentável, de fundo romântico. Dostoiévski aperfeiçoa como ninguém a descrição minuciosa dos estados paranoicos, como já destacava Otto Rank. ${ }^{28}$ A segunda aventura encaminha a terceira em seu término, que se dá na noitada no bordel ao qual o protagonista insiste em acompanhá-los. A insistência de comparecer ao bordel baseia-se tão-somente no desejo irrefutável do protagonista de vingar-se da presunção de Zvierkóv, almejando ter com ele uma briga, e, inclusive, desafiá-lo para um duelo (no qual precisaria igualmente pedir dinheiro emprestado para comprar as armas...).

A terceira aventura pode ser sintetizada pela longa conversa com a jovem prostituta Liza. Chegando no bordel logo após a saída dos companheiros aos quais perseguia, em função da dificuldade para alcançar o local, o narrador, ainda embriagado, ensopado de neve, ${ }^{29} \mathrm{e}$ frustrado por não poder enfrentar Zvierkóv, decide passar a noite com a jovem. Depois do subentendido ato carnal, o protagonista dorme, e quando acorda se impacienta por se encontrar na cama com Liza, que o encarava. $O$ que se enfileira a partir disso é uma série de questionamentos a propósito da vida da jovem, acompanhados de julgamentos severos, que tem como fim humilhá-la, aproveitando-se da condição de estar pagando por aquele serviço, pelas horas de atenção obrigada. O personagem é impiedoso com Liza, que de início apenas responde às perguntas com frases curtíssimas, mostrando-se ora indiferente, ora envergonhada, até não tolerar mais o suplício e desabar chorando. A reviravolta na aventura se dá à medida em que o protagonista repentinamente muda o tom do discurso e passa, ainda que de modo esquisito, a consolá-la e, em meio a isso, cortejá-la. Chega a convidá-la

\section{RANK, 1932.}

29 Lembremos que o signo da neve é um elemento persistente nas Memórias. A neve molhada que suja, que embarra, que atrapalha a livre circulação na cidade, que traz o frio e a umidade para dentro do corpo. 0 fechamento da primeira parte do livro - "Tenho a impressão de que foi justamente a propósito da neve molhada que lembrei esse episódio que não quer agora me deixar em paz" (p. 54) - traz a neve como uma espécie de objeto disfarçado que serve de gatilho para a contação das histórias que marcam a segunda parte, denominada, não à toa, $A$ propósito da neve molhada. 
para largar aquela vida e ir morar com ele. Escreve o endereço num papel e, antes de sair, entrega a Liza. Depois, evidentemente, oscilará em arrepender-se daquele gesto e esperá-la angustiadamente. Nesse evento, é interessante reparar em dois pontos: nas oscilações emotivas e impulsivas, devassas e moralistas, que marcam a trajetória do narrador e que aqui elevam-se a um turbilhão de descontrole, agressivo e simultaneamente piegas, assinalando outra vez a necessidade que tem de ofender, humilhar, em última análise, vingar-se, de pessoas aleatórias que só servem para momentaneamente aliviar sua raiva e horror perante o desconcerto do mundo. $O$ outro ponto, por fim, remete-se à liberdade confessional que o personagem assume somente em meio à degradação. De acordo com o que recorda, o quarto é sujo, cheira mal, é apertado e escuro; seu aspecto físico é tal qual deplorável, e é justamente nesse tipo de espaço, em frente à mulher que considera frágil, leviana e perdida (ele é obviamente misógino), que se sente à vontade para expor detalhes íntimos de sua vida e, por conseguinte, de seu pensamento: "ansiava já por expor minhas ideiazinhas secretas, cultivadas num canto. De súbito, algo se inflamou em mim, 'apareceu' não sei que objetivo". ${ }^{30}$ É nesse episódio que descobrimos a orfandade do protagonista, seu desejo - que nega a si mesmo - de dividir o tempo com alguém, de ter intimidade. A reação final de Liza é igualmente definitiva e, além de ofender o personagem, parece abrir o horizonte para que, de fato, ele escreva as memórias: "é que você... fala como se estivesse lendo um livro (...) - essa observação espicaçou-me dolorosamente. Não era o que eu esperava" ${ }^{31}$ Será Liza, sob a espontaneidade de um insight despercebido, quem desperta-lhe o chamado para escrever?

Noutro viés, mas já nem tão distante, é preciso atentar-se que Memórias do subsolo é um livro a propósito da construção de um livro, isto é, que acompanha um livro que está sendo primeiro reivindicado, depois feito e que inexplicavelmente para no meio do caminho (na última página, há a promessa

30 DOSTOIÉVSKI, 2009, p. 107.

$31 \mathrm{lbid}$, p. 114. 
de que as memórias irão continuar e fica subentendido que há ainda uma parte delas já escrita que extrapola o subsolo). A camada metaliterária não se reduz nitidamente a isso, pois as alusões ao ideal livresco por parte do narrador, à sátira ao romantismo no plano do autor - Dostoiévski satirizando o próprio romantismo de seus livros anteriores, como afirmaria René Girard -, são índices fundamentais para a compreensão da obra. As Memórias, em síntese, são o movimento em si do devir da literatura, ao vivo e em cores; é o processo cinético em sua manifestação e que pode ser observado durante a própria produção de produções, ou seja, trata-se de uma máquina-livro em andamento, informe e inacabada, como é a literatura em sua dimensão de devir. Haverá uma proposição de saúde nesse acontecimento estético que engloba não só a posição de Dostoiévski como escritor, mas também o intralocal do narrador memorialista como autor, ambos assumindo, sob um compartilhamento imanente, a potência dos "médicos da civilização", ${ }^{32}$ como veremos melhor adiante.

Por enquanto, grosso modo, digamos que a superfície central da narrativa não passa de um conjunto fragmentário de reclamações, de lamentos, de vitimizações e tentativas frustrantes de terceirizar culpas e empreender vinganças quase sempre obsoletas, risíveis, orientadas, de uma maneira triste, por um suscetível e confuso senso de justiça que constrange com frequência até mesmo o narrador: uma rede de gemidos ignobeizinhos infundados, para usar-se das palavras do per-

32 Dostoiévski, e propriamente o personagem das Memórias, nesse sentido, não se diferem de Sacher-Masoch e Proust, pois os grandes artistas "não são doentes; ao contrário, são médicos, médicos muito especiais. Por que Masoch dá seu nome a uma perversão tão antiga quanto o mundo? Não porque 'sofra' dela, mas porque ele lhe renova os sintomas, traçando dela um quadro original ao fazer do contrato o signo principal, e também ao ligar as condutas masoquistas à situação das minorias étnicas e ao papel das mulheres nessas minorias: o masoquismo torna-se um ato de resistência, inseparável de um humor de minorias. Masoch é um grande sintomatologista. Em Proust, não é a memória que é explorada, são todas as espécies de signos, dos quais é preciso descobrir a natureza de acordo com os meios, o modo de emissão, a matéria, o regime. Em busca do tempo perdido é uma semiologia geral, uma sintomatologia dos mundos" (DELEUZE, 2010, p. 182). Tal aproveitamento, é preciso ser dito, parte da afirmação de Nietzsche que revela o encontro entre o médico e o filósofo, isto é, o filósofo, ante a tarefa da genealogia, deve figurar como médico, artista e legislador, "philosophe médecin (c'est le médecin qui interprète les symptômes), philosophe artiste (c'est l'artiste qui modèle les types), philosophe législateur (c'est le législateur qui determine le rang, la généalogie)" (Id, 2018, p. 117). 
sonagem. Como que cobrindo os buracos que tal conjunto deixa pelo caminho, entram as inquietações filosóficas que talvez seja o que de mais valioso o texto resguarde e provoque. Muitos desses questionamentos, inclusive, parecem insólitos e são, em sua grande maioria, negativos: "pode porventura um homem consciente respeitar-se um pouco sequer"? ${ }^{33} \mathrm{~A}$ estrutura do livro, dividido em duas partes, estas subdivididas em curtas seções enumeradas, cumpre com a forma esperada das anotações memorialísticas, mas desvia-se ligeiramente no que concerne sua disposição interrogante. Ou melhor, o que causa estranhamento de antemão é que as memórias interrogam a todo tempo o leitor. Não são simplesmente o relato das experiências vividas por um eu triunfante, mas são sobretudo inquietações filosóficas que usam essa vida de fundo para o seu verdadeiro intuito de questionamento para fora - dimensão política e essencial da obra. Ou seja, num plano, cumpre-se a função do desabafo corriqueiro, porém noutro, desvela-se a insinuação satírica (a veia irônica que salta do trágico) que assume o leitor como uma meta ética. Ora, Bakhtin ${ }^{34}$ já havia chamado a atenção em relação à estrutura confessional específica das Memórias, mostrando como a narrativa se constrói na expectativa da palavra do outro, sobre alguém que ouça o protagonista e, de certo modo, o absolva, noutras palavras, que o assiste e lhe dê assistência. Nesse sentido, as notas recordam ações passadas, é certo; refletem a impressão presente sobre elas, mas principalmente jogam questões que dizem respeito a um tempo indefinido por vir, a uma etapa histórica e social, ainda nebulosa, que se encontra em gestação e que é preciso que o leitor a vislumbre. Um tempo que parece abrir-se ao passo que é sentido pela condição de sufocamento do narrador perante uma máquina-mundo já atrofiada, desgastada, que precisa se renovar para não repetir mais situações e sujeitos como aqueles. $O$ tom de praguejamento, a náusea para com a realidade, são índices que demandam caprichosamente esse novo tempo. E que certamente ressonam a crítica ao contexto presente em que esteve inserido um indivíduo como Dos-

33 DOSTOIÉVSKI, 2009, p. 28.

34 BAKTHIN, 1997. 
toiévski: crítica à crueldade e à estagnação do sistema tsarista, à brutalização das relações humanas frente ao cenário de exploração e miséria, ao atraso desenvolvimentista, industrial e progressista que a Rússia conservadora e agrária da época vivia em relação à Europa modernizada, e assim por diante, como bem sabemos. Porém, nessa amalgama toda, há espaço ainda para a crítica acertada ao sujeito pragmático e funcional do novo mundo, científico e empreendedor, que ilustra o recente capitalismo exterior, ${ }^{35}$ a partir de uma dialética da ação e da tranquilidade:

todos os homens diretos e de ação são ativos justamente por serem parvos e limitados (...) em virtude de sua limitada inteligência, tomam as causas mais próximas e secundárias pelas causas primeiras, e, deste modo, se convencem mais depressa e facilmente que os demais de haver encontrado o fundamento indiscutível para a sua ação e, então, se acalmam (...) para começar a agir, é preciso, de antemão, estar de todo tranquilo, não conservando quaisquer dúvidas. ${ }^{36}$

Dessa maneira, por outro lado, portanto, é que o narrador, esmagado também pelo enfado e pela consciência hipertrofiada da inercia que o circunda, desenvolve certa vontade outra vez quixotesca - mas também bovarysta - de viver o que lia nos livros na sufocante vida concreta, aí havendo, por consequência, uma imperiosa disputa pelo real, ou pelos efeitos de realidade, para evocarmos de passagem o célebre debate orientado por Roland Barthes ${ }^{37}$ e reanimado recentemente por Jacques Rancière, ${ }^{38}$ trazendo à tona a disputa pelas políticas da ficção.

\footnotetext{
35 Georges Lukács (1964, p. 119) já estava atento a tais circunstâncias em Dostoiévski: "Em uma importante narrativa, Memórias do subsolo, ele foi um dos primeiros a descrever, em um modo decadente, a solidão humana (...) 0 que sobretudo faz com que os heróis de Dostoiévski sofram é a desumanidade própria do capitalismo nascente, e, mais diretamente, a que marca todas as relações inter-humanas. Forçado a viver em um mundo contra o qual se revolta, com todas as fibras de seu ser, recusa com a mesma paixão a perspectiva de uma solução socialista (palácio de cristal, formigueiro, etc.). 0 protesto contra o capitalismo desumano transforma-se então em uma crítica ao socialismo e da democracia, fundada em sofismas assimilativos e em um anticapitalismo de tipo romântico".
}

36 DOSTOIÉVSKI, 2009, p. 29.

37 Cf. BARTHES, Roland. L'effet de réel. Communications, Année 1968, (11). In: https://www. persee.fr/doc/comm_0588-8018_1968_num_11_1_1158

38 Cf. RANCIĖRE, Jacques. 0 efeito de realidade e a política da ficção. Tradução de Carolina Santos. Novos estudos. CEBRAP (86), mar 2010. 
Esse mergulho teórico, por exemplo, pode servir para vermos como, de fato, a camada supérflua da fantasia wertheriana do protagonista camufla o verdadeiro plano político que Dostoiévski já ensaiava de modo talvez ainda enigmático nas $\mathrm{Me}$ mórias, mas que será desenvolvido com maior clareza e fôlego a partir de Crime e castigo e d'Os demônios.

Dito isso, é preciso também lembrar que o micróbio esnobe que vemos relatar suas andanças-trauma tem, ainda por cima, um empregado doméstico (Apolon) mais arrogante que ele mesmo, e que o despreza, como ocorre a todos que cruzam seus itinerários. Evidentemente, Apolón é odiado pelo patrão miserável, espécie esquizoide de posição social admitida no contexto em parte ainda medieval que sustenta o momento russo. Apolón é retratado como um sujeito indiferente, blasé, superior, e é definido como um carrasco pelo narrador. A única personagem do enredo, porém, que não o despreza será Liza, a jovem de Riga que recém entrara no universo da prostituição e já possuía dívidas com a casa de tolerância. O narrador, entretanto, não sossegará até conseguir fazer que ela igualmente o despreze. Liza, em princípio, é seduzida pela persona literária improvisada pelo protagonista para aconselhá-la e inclusive consolá-la na noite em que se conhecem no bordel clandestino. Depois que Liza lhe visita em casa, ela passa a conhecer e a aparentemente gostar de súbito da pessoa decadente que é na verdade o homem do subsolo, descoberto por trás da fantasia de cavalheiro romântico à moda russa, um Werther cossaco. A cena em que ambos se abraçam e choram juntos durante alguns minutos é, de fato, deplorável, mas também revela a essência real do encontro entre os dois pobres-diabos abandonados no mundo: "ela se lançou subitamente a mim, rodeou-me o pescoço com os braços e chorou. Eu também não resisti e chorei aos soluços, de modo como nunca ainda me acontecera..." ${ }^{39}$ Contudo, o anti-herói das Memórias não pode suportar a aproximação afetiva, sendo incapaz de qualquer empatia, e principalmente não consegue tolerar que seu lado real tenha-

In: https://www.scielo.br/j/nec/a/4twWJzZKqthNjSyHxVnwtTP/?lang=pt

39 DOSTOIÉVSKI, 2009, p. 140. 
sido desnudado pela jovem que decide supostamente tentar amá-lo. A renúncia a essa possibilidade de afeto rapidamente faz com que ele a humilhe para que ela de imediato deixe de tentar amá-lo. A ideia de amor para o protagonista, além disso, vincula-se a traços que ressonam uma postura típica aos personagens de Sacher-Masoch - a Vênus das peles, não à toa, é uma novela de $1870^{40}$ - : "bem certo é que eu não posso viver sem autoridade e tirania sobre alguém..." ." A concepção de amor revelada pelo narrador é intrigante e merece destaque:

$\mathrm{Eu}$ não podia mais apaixonar-me, porque, repito, amar significava para mim tiranizar e dominar moralmente (...) chego a pensar por vezes que o amor consiste justamente no direito que o objeto amado voluntariamente nos concede de exercer tirania sobre ele. Mesmo nos meus devaneios subterrâneos, nunca pude conceber o amor senão como uma luta: começava sempre pelo ódio e terminava pela subjugação moral; depois não podia sequer imaginar o que fazer com o objeto subjugado. ${ }^{42}$

Os cinco rublos deixados por Liza, instantes antes de abandoná-lo de vez, em cima da mesa - dinheiro que ele havia recém dado a ela como alguma forma delirante de recompensa - parece ser o profundo motivo de sua ruína pessoal e de seu decorrente isolamento radical na própria cova que prepara para si no subterrâneo. Nessa esteira, é ainda interessante reparar que há um sistema de dívidas que amarra o enredo. Algumas questões surgem a respeito disso: como e quanto tempo precisou o protagonista para pagar seus empréstimos, se é que, de fato, foram quitados? Sua opção pelo isolamento não pode também refletir seu escape dos pagamentos ou a vergonha moral de talvez não os pagar? A própria situação de Liza tem como fundo seu endividamento gradual com o prostíbulo... O abismo de um sistema econômico brutalmente desigual dos tempos despóticos do tsarismo é deflagrado molecularmente no tecido do texto.

40 Cf. FARINA, Diego Lock. 1870 - 0 agenciamento Masoch, 0 agenciamento das peles. Porto Alegre: Revista Philia, v. 1, n. 1 (2019). In: https://seer.ufrgs.br/philia/article/ view/86984

41 DOSTOIÉVSKI, 2009, p. 141.

42 Ibid, p. 142. 
A título de desfecho, é preciso aferir que a trajetória desse personagem tão desafiante cumpre em parte com o slogan que ele próprio cria para si: um homem doente, mau e desagradável..., dono, por conseguinte, de um rancor frígido, de um desencanto cínico e, por fim, de uma zombaria lúcida que não podemos deixar de lado. Entretanto, tal descrição negativa não sustenta de todo a complexidade do devir das Memórias. A indagação que surge daí é simples: estará mesmo enfermo o homem desagradável do subsolo? Enfermo do fígado, como ele mesmo ironicamente diz? A hipótese que queremos aqui ensaiar vem da assimilação atenta de um dos trechos finais da obra, em que o narrador concebe seu esforço de escrita, materializado no livro que lemos, como um "castigo correcional" ${ }^{43} \mathrm{O}$ que parece fortuito para pensarmos a possibilidade, condizente com o estatuto de paradoxalista por excelência por parte do protagonista, de o real devir do narrador ser o próprio trânsito entre a enfermidade e a saúde, entre o doente e o médico da civilização. É evidente que, quando nos referimos aqui à saúde, dirigimo-nos exclusivamente à noção de saúde da literatura desenvolvida por Deleuze, e pensamos na dupla figuração indissociável entre Dostoiévski e seu personagem-autor acerca disso:

Não se escreve com as próprias neuroses. A neurose, a psicose não são passagens de vida, mas estados em que se cai quando o processo é interrompido, impedido, colmatado. A doença não é processo, mas parada do processo, como no caso de Nietzsche. Por isso o escritor, enquanto tal, não é doente, mas antes médico, médico de si próprio e do mundo. O mundo é o conjunto dos sintomas cuja doença se confunde com o homem. A literatura aparece, então, como um empreendimento de saúde: não que o escritor tenha forçosamente uma saúde de ferro (haveria aqui a mesma ambiguidade que no atletismo), mas ele goza de uma saúde frágil irresistível, que provém do fato de ter visto e ouvido coisas demasiado grandes para ele, fortes demais, irrespiráveis, cuja passagem o esgota, dando-lhe, contudo, devires que uma gorda saúde dominante tornaria impossíveis. Do que viu e ouviu, o escritor regressa com os olhos vermelhos, com os tímpanos perfurados. Qual saúde bastaria para libertar a 
vida em toda parte onde esteja aprisionada pelo homem e no homem, pelos organismos e gêneros e no interior deles? ${ }^{44}$

A saúde do empreendimento que é a literatura liberta a vida aprisionada no homem. Ora, o homem do subsolo, ao atingir a saúde frágil, porém irresistível do escritor, passa a ser capaz de exorcizar, de conjurar os próprios demônios que o afligem, afinal, a escrita é seu castigo correcional. Há uma espécie de cura nesse processo de escrita: a ambiguidade do paradoxalista, do pêndulo entre o bem e o mal, aporético, concretiza-se, com efeito, quando ele mesmo devém literário, materialidade estética, um ser-de-literatura que se escreve e, sobretudo, inscreve-se na realidade virtual das ideias, seja a partir das memórias, seja a partir do pensamento crítico, político-filosófico, que desenvolve e atira ao leitor sob o módulo do questionamento. A saúde que o protagonista alcança é a saúde dos que se habilitam a diagnosticar a sociedade, capturar seus sintomas, tratá-los, no limite, e é por isso que a condição doentia do protagonista se torna relativa. A própria filosofia do desejo esboçada na primeira parte do livro é um indício da conquista desse estado de pertença ao exercício de uma crítica-clínica que se abastece dos delírios, das linhas de fuga, daquilo é forte demais para vermos e que poucos viram e saíram resistentes desse acontecimento; no plano do empirismo-transcendental - porque, de fato, o personagem experimenta e supera-se, transpondo-se - lemos as memórias escritas por um sujeito já impessoal que assume o corpo atômico de que falava Artaud, ${ }^{45}$ no lugar do corpo anatômico que enfraquece e enferma, ou seja, é na literatura, enquanto literatura, que o personagem adquire seu corpo sem órgãos, através da disciplina do sofrimento, que produz suas elevações, da libertação gradual do orgulho que reprime o fluxo da memória, falsificando-a, e, por fim, do extravasamento da estrutura binária do bem e do mal. O homem do subsolo é um viajante em trânsito, que perde países, mas que ganha espaço num plano que agora está intocável: o subsolo enquanto lugar impossível da instabilidade afirmativa, ou, então, a instabilidade afirmativa como

44 DELEUZE, 2011, p. 14.

45 GROSSMANN, 2003, p. 11. 
o subsolo do lugar que vem, e que, todavia, propriamente não veio, porque há muito ainda para corrigir.

\section{Referências bibliográficas}

BAKHTIN, Mikhail. Problemas da poética de Dostoiévski. Tradução de Paulo Bezerra. Rio de Janeiro: Forense Universitária, 1997.

DELEUZE, Gilles. Imanência: uma Vida... Tradução de Sandro Kobol Fornazari. São Paulo: Limiar - vol. 2, $\mathrm{n}^{\circ} 4-2^{\circ}$ semestre de 2016.

DELEUZE, Gilles. Nietzsche et la philosophie. Paris: PUF, 2018. DELEUZE, Gilles. "A literatura e a vida". In: Crítica e clínica. Tradução de Peter Pál Pelbart. São Paulo: Editora 34, 2011.

DELEUZE, Gilles. "Sobre a filosofia". In: Conversações. Tradução de Peter Pál Pelbart. São Paulo: Editora 34, 2010.

DELEUZE, Gilles; GUATTARI, Félix. "1730 - Devir-intenso, devir-animal, devir-imperceptível..." In: Mil platôs, v.4. Tradução de Suely Rolnik. São Paulo: Editora 34, 2012.

DOSTOIÉVSKI, Fiódor. Memórias do subsolo. Tradução de Boris Schnaiderman. São Paulo: Editora 34, 2009.

FARINA, Diego Lock. A teoria crítico-clínica e a política da literatura fora da representação: acontecimento e devir e diferença... Porto Alegre: LUME-UFRGS, 2021. Disponível em: http:// hdl.handle.net/10183/223930. Acesso em: 14 out. 2021.

GIRARD, René. Dostoiévski: do duplo à unidade. Tradução de Roberto Mallet. São Paulo: Realizações Editora, 2011.

GIVONE, Sergio. "Dizer as emoções. A construção da interioridade no romance moderno". In: A cultura do romance. Org: Franco Moretti. Tradução de Denise Bottmann. São Paulo: Cosacnaify, 2009.

GROSSMAN, Évelyne. "Le corps-xylophène d'Antonin Artaud (Préface)". In: Pour en finir avec le jugement de dieu. Paris: Éditions Gallimard, 2003. 
LUKÁCS, Georges. Significado presente do realismo crítico. Tradução de Carlos Saboga. Lisboa: Cadernos de hoje, n5, 1964. NIETZSCHE, Friedrich. Além do bem e do mal. Tradução de Renato Zwick. Porto Alegre: L\&PM, 2010.

RANK, Otto. Don Juan. Une étude sur le double. Paris: Denoël et Steele, 1932.

Recebido em: 15/10/2021 Aceito em: 02/12/2021 